INVITED REVIEW

\title{
Defective nitric oxide synthesis: a link between metabolic insulin resistance, sympathetic overactivity and cardiovascular morbidity
}

Urs Scherrer and Claudio Sartori

Department of Internal Medicine and Botnar Centre for Clinical Research, Centre Hospitalier Universitaire Vaudois, Lausanne, Switzerland

(Correspondence should be addressed to U Scherrer, Department of Internal Medicine, BH 10.642, CHUV, CH-1011 Lausanne, Switzerland; Email: Urs.Scherrer@chuv.hospvd.ch)

\begin{abstract}
Epidemiological studies demonstrate an association between insulin resistance, hypertension and cardiovascular morbidity. In addition to its metabolic effects, insulin also has important cardiovascular actions. The sympathetic nervous system and the nitric oxide-L-arginine pathway have emerged as central players in the mediation of these actions. Over the past decade, the underlying mechanisms and the factors that may govern the interaction between insulin and these two major cardiovascular regulatory systems have been studied extensively in healthy people and insulinresistant individuals. Here we summarize the current understanding and gaps in knowledge on these interactions. We propose that a genetic and/or acquired defect of nitric oxide synthesis could represent a central defect triggering many of the metabolic, vascular and sympathetic abnormalities characteristic of insulin-resistant states, all of which may predispose to cardiovascular disease.
\end{abstract}

European Journal of Endocrinology 142 315-323

\section{Introduction}

Epidemiological observations demonstrate an association between obesity, insulin resistance and hypertension $(1,2)$ and indicate that insulin is an independent predictor of coronary artery disease (3). The underlying mechanism relating these disorders is not known. Over the past decade evidence has accumulated indicating that insulin, in addition to its metabolic action, exerts cardiovascular effects that are mediated by the sympathetic nervous system and the nitric oxide-L-arginine pathway. Insulin-resistant states are characterized by alterations in both of these functions. Recent evidence indicates that these two regulatory systems interact closely and a defect in nitric oxide synthesis may have important consequences with regard to sympathetic function. In this paper we will review studies examining vascular and sympathetic function in insulin-resistant states. We will then try to demonstrate how a genetic and/or acquired defect in nitric oxide synthesis could represent a central defect triggering many of the metabolic, vascular and sympathetic abnormalities that characterize insulin-resistant states.

\section{Impaired nitric oxide synthesis: a defect underlying sympathetic overactivity and impaired vasodilatation in insulin- resistant states}

\section{Physiology: interplay between nitric oxide and the sympathetic nervous system in the mediation of the cardiovascular actions of insulin in normal individuals}

Short-term infusion of insulin (4-14) and carbohydrate ingestion (15-17) stimulate sympathetic nerve activity in normal individuals. Insulin stimulation of sympathetic outflow is targeted specifically at the skeletal muscle tissue $(17,8,18)$ - the main target of the metabolic action of insulin. This sympathoexcitatory effect appears to be mediated by a central neural action of insulin $(4,6,11,19-22)$ possibly involving the release of specific neuropeptides such as corticotrophin releasing hormone (10).

In healthy individuals, insulin also stimulates blood flow and decreases vascular resistance in skeletal muscle $(9,10,14,22-35)$ but not in skin $(29,35)$. Insulin 
stimulation of blood flow is characterized by interindividual variability (29) that appears to be determined, at least in part, by the relative limb muscle content and related phenomena such as physical fitness and capillary : fibre ratio $(36,37)$. Insulin vasodilatation is related primarily to insulin itself rather than to stimulation of carbohydrate metabolism (14).

Nitric oxide release accounts for the vasodilator action of insulin (22). In vitro, insulin activates L-arginine transport and stimulates nitric oxide release in cultured vascular endothelial cells $(38,39)$. In vivo, insulin-induced vasodilatation is abolished by the stereospecific inhibitor of nitric oxide synthase, $N^{\mathrm{G}}$-monomethyl-L-arginine (L-NMMA) $(31,40)$, and by inhibition of the synthesis of tetrahydrobiopterin, a cofactor necessary for nitric oxide synthesis (41). Insulin potentiates endothelium-dependent but not endothelium-independent vasodilatation, indicating that its vasodilator effect is related specifically to stimulation of nitric oxide release, and not to facilitation of vascular responsiveness to nitric oxide $(42,43)$.

Insulin may stimulate nitric oxide release either by a direct, local effect at the vascular endothelium or by stimulating sympathetic nitrergic fibres. Comparison of vasodilatation during local, intra-arterial and systemic, intravenous insulin infusion has provided conflicting results (22). In patients who have undergone regional sympathectomy, insulin stimulates nitric oxide release and blood flow in the denervated limb, indicating that it stimulates blood flow by a direct action at the vasculature (44). Consistent with this hypothesis, insulin causes hypotension in patients with autonomic failure (45). In innervated limbs, however, stimulation of sympathetic vasodilator outflow by insulin appears to be necessary to induce vasodilatation, because the prevention of insulininduced sympathetic activation by means of dexamethasone abolished the insulin-induced vasodilatation (10).

The sympathetic nervous system modulates insulininduced vasodilatation, as indicated by the much more rapid vasodilatation in the denervated than in the innervated limb in patients with regional sympathectomy $(46,47)$. Moreover, it is possible that there exists a balance between the central neural sympathoexcitatory (via stimulation of neural peptide release) and sympathoinhibitory (by stimulating nitric oxide release) actions of insulin, as nitric oxide inhibits central neural sympathetic vasoconstrictor outflow $(48,49)$.

In summary, insulin causes vasodilatation by stimulating release of nitric oxide through a direct local effect at the vasculature and by stimulating neural vasodilator outflow. The sympathetic vasoconstrictor tone restricts the insulin-induced vasodilatation.

\section{Pathophysiology: insulin resistance is associated with a defect in nitric oxide synthesis and sympathetic overactivity}

Many studies have examined insulin cardiovascular effects in insulin-resistant states $(9,23,25,32,43$, 50-81) and most, but not all, of these studies show that insulin-induced vasodilatation is impaired in obesity, essential hypertension and non-insulindependent diabetes mellitus (NIDDM) (Table 1). The reason for the divergent findings between studies is not clear, but could be related to confounding factors that were not controlled for, such as glycaemic control (82), dyslipidaemia (52), dysautonomia $(78,79)$, long-term complications of NIDDM and differences in the techniques and pharmacological agents used to assess endothelial function.

There is increasing evidence that in insulinresistant individuals, in addition to insulin vasodilatation, endothelium-dependent vasodilatation is also impaired (Table 1). Insulin stimulation of nitric oxide flux in skeletal muscle tissue is defective in obese persons (83). Impaired endothelial nitric oxide synthesis has been shown to be directly related to metabolic insulin resistance (84). In vitro, insulin stimulation of nitric oxide release and glucose metabolism appear to share common signalling pathways in vascular endothelial cells, suggesting that the vascular and metabolic actions of insulin may be coupled (39). Alternatively, insulin resistance is associated with metabolic abnormalities such as dyslipidaemia that, in turn, may alter endothelial function. The mechanism underlying the endothelial dysfunction is not known.

Insulin resistance is associated with sympathetic overactivation in both animals and humans $(13,15$, $16,85-88)$. The mechanism causing this sympathetic overactivity is not known. Hyperinsulinaemia is a candidate mechanism, but is not invariably associated with sympathetic overactivity in humans, as demonstrated by the normal sympathetic nerve activity in patients with insulinoma (89, 90) and alternative mechanisms need to be considered. Nitric oxide inhibits central neural vasoconstrictor outflow in animals (91-93) and humans $(49,48)$. It is therefore possible that the defect in nitric oxide synthesis found in many insulin-resistant states (83, 94) may contribute to sympathetic overactivity. This defect in nitric oxide synthesis could be acquired and/ or inherited. With regard to an inherited defect, recent studies indicate that polymorphisms in the endothelial nitric oxide synthase gene are risk factors for cardiovascular diseases associated with insulin resistance such as hypertension (95) and coronary artery disease $(96,97)$.

In summary, there is increasing evidence that nitric oxide synthesis is impaired in insulin-resistant states. This defect may be inherited and/or acquired and could contribute to both impaired insulin-induced vasodilatation and sympathetic overactivity characteristic of insulin-resistant states. 
Table 1 Summary of the studies examining vascular responsiveness in insulin resistant states.

\begin{tabular}{|c|c|c|c|c|}
\hline $\begin{array}{l}\text { Insulin } \\
\text { resistant state }\end{array}$ & $\begin{array}{l}\text { Endothelium- } \\
\text { dependent } \\
\text { vasodilatation }\end{array}$ & $\begin{array}{l}\text { Endothelium- } \\
\text { independent } \\
\text { vasodilatation }\end{array}$ & $\begin{array}{l}\text { Insulin-mediated } \\
\text { vasodilatation }\end{array}$ & Reference \\
\hline \multicolumn{5}{|l|}{ Obesity } \\
\hline & ND & ND & Normal & 50 \\
\hline & Normal & Normal & Blunted & 51 \\
\hline & ND & ND & Blunted & 23 \\
\hline & ND & ND & Blunted & 9 \\
\hline \multirow[t]{3}{*}{ (and NIDDM) } & ND & ND & Blunted & 25 \\
\hline & Impaired & Normal & ND & 52 \\
\hline & Impaired & ND & ND & 53 \\
\hline \multicolumn{5}{|l|}{ Hypertension } \\
\hline & Impaired & ND & Normal & 43 \\
\hline & ND & ND & Normal & 54 \\
\hline & ND & ND & Normal & 32 \\
\hline \multirow{4}{*}{ (and obesity) } & ND & ND & Normal & 55 \\
\hline & ND & ND & Blunted & 56 \\
\hline & ND & ND & Blunted & 57 \\
\hline & ND & ND & Blunted & 58 \\
\hline \multirow[t]{8}{*}{ (and obesity) } & ND & ND & Blunted & 59 \\
\hline & ND & ND & Blunted & 60 \\
\hline & ND & ND & Blunted & 61 \\
\hline & Normal? & Normal? & Blunted? & 62 \\
\hline & Impaired & ND & ND & 63 \\
\hline & Normal & ND & ND & 64 \\
\hline & Impaired & ND & ND & 65 \\
\hline & Impaired & ND & ND & 66 \\
\hline \multicolumn{5}{|l|}{ NIDDM } \\
\hline & ND & ND & Normal & 67 \\
\hline & ND & ND & Normal & 68 \\
\hline & ND & ND & Normal & 69 \\
\hline & ND & ND & Normal & 70 \\
\hline & ND & ND & Normal & 71 \\
\hline & ND & ND & Blunted & 72 \\
\hline & ND & ND & Blunted & 73 \\
\hline & Normal & Normal & ND & 74 \\
\hline & Impaired & Impaired & ND & 75 \\
\hline \multicolumn{5}{|l|}{ IDDM } \\
\hline & ND & ND & Normal & 76 \\
\hline & ND & ND & Blunted & 77 \\
\hline & ND & ND & Exaggerated & 78 \\
\hline & Exaggerated & Exaggerated & ND & 79 \\
\hline & ND & ND & Blunted & 80 \\
\hline & Impaired & ND & ND & 81 \\
\hline
\end{tabular}

\section{Pathophysiological consequences of defective nitric oxide synthesis (and sympathetic overactivity)}

\section{Metabolic consequences of impaired nitric oxide synthesis: flow-dependent and -independent effects}

As insulin increases muscle blood flow, the obvious question arises whether this effect has a role in its main action - namely the promotion of glucose disposal in skeletal muscle tissue. Stimulated by the pioneering study by Laakso and colleagues, who provided evidence consistent with this hypothesis (23), many subsequent investigations have examined the effects of an acute augmentation or inhibition of muscle blood flow on insulin-stimulated muscle glucose uptake in both healthy and insulin resistant individuals. Since our last review (22) this issue has remained highly controversial and is far from being definitively settled $(82,98,99)$. These conflicting results may be related, at least in part, to differences in study design, dose and pharmacology of the vasoactive agents used, the absence of reliable tools for the direct assessment of muscle microcirculation (100), confounding effects of these drugs on other systems known to modulate glucose metabolism, and confounding flow-independent effects of these agents on glucose uptake $(22,94)$.

Specifically, the role of insulin stimulation of nitric oxide release and vasodilatation in the regulation of 
muscle glucose uptake is not clear. Stimulation of blood flow, and presumably the release of nitric oxide, by infusion of methacholine into the femoral artery has been reported to potentiate insulin-induced stimulation of regional glucose uptake during steady-state physiological and pharmacological hyperinsulinaemia (101), whereas acute reduction of femoral blood flow, and presumably nitric oxide release, by intra-arterial infusion of L-NMMA had the opposite effects (102). Conversely, induction of hypertension and inhibition of nitric oxide synthesis by infusion of L-NMMA did not alter stimulation of whole-body glucose uptake and glucose oxidation during insulin/glucose infusion in healthy individuals $(31,44,103)$ and stimulation of muscle blood flow by intra-arterial infusion of bradykinin did not augment regional muscle glucose uptake in normal individuals (34).

Nitric oxide may have effects on glucose metabolism that are independent of its vascular actions $(104,105)$. It is synthesized in skeletal muscle where it regulates metabolic and contractile processes (106). In incubated rat skeletal muscle, inhibition of nitric oxide synthase activity impaired contraction-stimulated (but not insulin-stimulated) glucose transport $(104,105,107,108)$, whereas nitric oxide donors had the opposite effect (105). In humans, improved glucose tolerance and insulin sensitivity characteristic of the trained state may be related to an augmented expression of nitric oxide synthase protein in skeletal muscle tissue (106). In keeping with this hypothesis, infusion of L-arginine augments insulin sensitivity by a mechanism independent of insulin-mediated vasodilatation (109). In addition to these peripheral actions, central neural nitric oxide-dependent pathways may also modulate insulin sensitivity, as indicated by the induction of insulin resistance in rats by intracerebroventricular administration of L-NMMA (110). Finally, and most importantly, mice with disruption of the gene encoding endothelial nitric oxide synthase are insulin resistant, as demonstrated by a roughly $40 \%$ smaller insulinstimulated whole-body glucose uptake than occurs in their wild-type littermates (H Duplain, C Sartori \& U Scherrer, unpublished observations). The underlying mechanism relating nitric oxide deficiency and insulin resistance in these mice remains to be elucidated. Similarly, the mechanism by which the infusion of L-NAME attenuates insulin-stimulated whole-body glucose disposal and the rate of disappearance of plasma $2-\left[{ }^{3} \mathrm{H}\right]$ deoxyglucose in conscious rats $(111)$ and how a defect in endothelial nitric oxide synthesis relates to insulin resistance in healthy humans (84) are not clear yet.

Sympathetic overactivity that may be related to defective nitric oxide synthesis could also contribute to metabolic insulin resistance. In healthy individuals acute, short-term sympathetic activation inhibits insulin stimulation of glucose metabolism $(33,112-114)-$ an effect that is reversed by $\alpha$-adrenergic blockade
(112). Consistent with the findings of these short-term studies, long-term treatment with $\alpha$-adrenergic antagonists increases insulin sensitivity in spontaneously hypertensive rats (115) and obese patients with hypertension (116). In the clinical setting, pathological states associated with sympathetic overactivity in skeletal muscle such as obesity $(13,87,88)$, heart failure (117) and hypertension (11) are characterized by insulin resistance and endothelial dysfunction.

\section{Cardiovascular consequences of impaired nitric oxide synthesis}

There exists an association between obesity, insulin resistance and hypertension $(1,2)$ and insulin is an independent predictor of coronary artery disease (3). The underlying mechanism relating these disorders is not known. Insulin resistance, however, is believed to play an important part because it often persists during antihypertensive treatment (118) and, although not found in secondary hypertension $(119,120)$, is present in offspring of hypertensive parents (who are prone to develop hypertension later in their life) at a time when they are still normotensive (121).

In humans, short-term infusion of insulin does not increase arterial pressure $(8,10,12,14,60)$ because the sympathetic pressor effects are offset by vasodilatation, as demonstrated by the induction of hypertension by insulin/glucose infusion during nitric oxide synthase inhibition $(31,47)$. The observation in patients with autonomic failure that unopposed insulin-induced vasodilatation is associated with marked hypotension further demonstrates the importance of this balance between the pressor and depressor actions of insulin for blood pressure regulation (45). It is therefore possible that the endothelial dysfunction found in insulinresistant states $(43,52,61,66)$ may tip the balance between the pressor and depressor actions in favour of the former and ultimately lead to hypertension. In obese insulin-resistant individuals, the conjunction of sympathetic overactivity and impaired nitric oxide synthesis not only may favour hypertension, but could potentiate overall cardiovascular risk. Sympathetically mediated trophic effects on the vasculature (122) and stimulation of platelet number and aggregability (123) together with the loss of nitric oxide inhibition of such actions (124-126) could trigger acute cardiovascular events. In the presence of preserved insulin-stimulated atherogenesis (82), impaired insulin-stimulated nitric oxide synthesis and, in turn, inhibition of atherogenesis, could provide a link between insulin resistance and macrovascular disease (3). Finally, an inherited defect (127) in nitric oxide synthase not only may alter sympathetic regulation and impair antithrombotic and antiatherogenic defence mechanisms, but may also underly the poor capillary development that characterizes young adults predisposed to arterial hypertension 




Figure 1 Simplified representation of how a defect in nitric oxide synthesis could cause many of the metabolic, vascular and sympathetic abnormalities characteristic of insulin-resistant states, all of which may predispose to cardiovascular disease.
(128), as vasodilatation and stimulation of blood flow are determinants of angiogenesis (129). Such an inherited impairment of nitric oxide synthesis may then be further aggravated by acquired factors such as obesity and physical inactivity.

In summary, animal species and human populations in whom insulin-resistance is associated with a high incidence of cardiovascular complications are characterized by possibly causally related sympathetic overactivity and a defect in nitric oxide synthesis. The mechanisms governing the interaction between these two systems are still incompletely understood. What is already clear, however, is that the conjunction of these two defects greatly potentiates the overall cardiovascular risk.

\section{Conclusion}

The data summarized in this review are consistent with the novel concept that a genetic and/or acquired impairment of nitric oxide synthesis may represent a central defect causing many of the metabolic, vascular, and sympathetic abnormalities associated with insulin resistance (Fig. 1). Impaired nitric oxide synthesis explains the defect in endothelium-dependent and insulin-induced vasodilatation that characterizes many insulin-resistant states and which in part may be related to poor development of capillary density and, in turn, vasodilator reserve. Nitric oxide inhibits sympathetic vasoconstrictor outflow. Thus defective nitric oxide synthesis may contribute to the sympathetic overactivity that characterizes these conditions. Finally, mice with disruption of the gene encoding for endothelial nitric oxide synthase are insulin resistant. The underlying mechanism by which a defect in nitric oxide synthesis causes metabolic insulin resistance is not yet known, but impaired insulin stimulation of muscle blood flow (and in turn substrate delivery), sympathetic overactivity and defective insulin signalling in the skeletal muscle cell may represent candidate mechanisms. In the clinical setting, impaired nitric oxide synthesis, sympathetic overactivity and hyperinsulinaemia concur in their proatherogenic actions. This unfavorable triad could promote hypertension by stimulation of vascular smooth muscle cell growth and vasoconstriction, and trigger acute coronary events by facilitating coronary vasoconstriction and platelet aggregation. We suggest that the pursual of this important avenue of research will generate important new insight into the underlying mechanisms linking cardiovascular and metabolic disease.

\section{Acknowledgements}

We would like to thank Drs Peter Vollenweider, Denis Randin, Laurent Vollenweider, Reza Owlya, Lionel Trueb, Mattia Lepori, Hervé Duplain, Marc Egli and Luc Tappy for their invaluable contributions to this work. We are indebted to Professors Pascal Nicod and Eric Jéquier for their superb support and many stimulating discussions, and to Dr Peter Vollenweider for the critical review of the manuscript. The authors' research was supported by grants from the Swiss National Science Foundation (32-28668.90, 3236280.92 and 32-046 797), the International Olympic Committee, the Emma Muschamp Foundation and the Placide Nicod Foundation.

\section{References}

1 Modan M, Halkin H, Almog S, Lusky A, Eshkol A, Shefi M, Shitrit A \& Fuchs Z. Hyperinsulinemia. A link between hypertension, obesity, and glucose intolerance. Journal of Clinical Investigation 198575 809-817.

2 Lucas CP, Estigarribia JA, Darga LL \& Reaven GM. Insulin and blood pressure in obesity. Hypertension 19857 702-706.

3 Desprès J-P, Lamarche B, Mauriège P, Cantin B, Dagenais GR, Moorjani S \& Lupien P-J. Hyperinsulinemia as an independent risk factor for ischemic heart disease. New England Journal of Medicine 1996334 952-957.

4 Pereda SA, Eckstein JW \& Abboud FM. Cardiovascular responses to insulin in the absence of hypoglycemia. American Journal of Physiology 1962202 249-252.

5 Tomiyama H, Kushiro T, Abata H, Kuruatani H, Taguchi H, Kuga N, Saito F, Kobayashi F, Otsuka Y, Kanmatsue K \& 
Kajiwara N. Blood pressure response to hyperinsulinemia in saltsensitive and salt-resistant rats. Hypertension $199220596-$ 600 .

6 Muntzel MS, Morgan DA, Mark AL \& Johnson AK. Intracerebroventricular insulin produces nonuniform regional increases in sympathetic nerve activity. American Journal of Physiology 1994267 R1350-R1355.

7 Rowe JW, Young JB, Minaker KL, Stevens AL, Pallotta JA \& Landsberg L. Effect of insulin and glucose infusions on sympathetic nervous system activity in normal man. Diabetes $198130219-225$.

8 Berne C, Fagius J, Pollare T \& Hjemdahl P. The sympathetic response to euglycaemic hyperinsulinaemia: evidence from microelectrode nerve recordings in healthy subjects. Diabetologia $199235873-879$.

9 Vollenweider P, Randin D, Tappy L, Jéquier E, Nicod P \& Scherrer U. Impaired insulin-induced sympathetic neural activation and vasodilation in skeletal muscle in obese humans. Journal of Clinical Investigation 199493 2365-2371.

10 Scherrer U, Vollenweider P, Randin D, Jéquier E, Nicod P \& Tappy L. Suppression of insulin induced sympathetic activation and vasodilation by dexamethasone in humans. Circulation 199388 388-394.

11 Lembo G, Napoli R, Capaldo B, Rendina V, Iaccarino G, Volpe M, Trimarco B \& Saccà L. Abnormal sympathetic overactivity evoked by insulin in skeletal muscle of patients with essential hypertension. Journal of Clinical Investigation $19929024-29$.

12 Anderson EA, Hoffman RP, Balon TW, Sinkey CA \& Mark AL. Hyperinsulinemia produces both sympathetic neural activation and vasodilation in normal humans. Journal of Clinical Investigation $1991872246-2252$.

13 Scherrer U, Randin D, Tappy L, Vollenweider P, Jéquier E \& Nicod P. Body fat and sympathetic nerve activity in healthy subjects. Circulation 199489 2634-2640.

14 Vollenweider P, Tappy L, Randin D, Schneiter P, Jéquier E, Nicod $\mathrm{P} \&$ Scherrer U. Differential effects of hyperinsulinemia and carbohydrate metabolism on sympathetic nerve activity and muscle blood flow in humans. Journal of Clinical Investigation $199392147-154$

15 Hwang IS, Ho H, Hoffman BB \& Reaven GM. Fructose-induced insulin resistance and hypertension in rats. Hypertension 1987 14 117-119.

16 Young JB, Saville E, Rothwell NJ, Stock MJ \& Landsberg L. Effect of diet and cold exposure on norepinephrine turnover in brown adipose tissue in the rat. Journal of Clinical Investigation 198269 1061-1071.

17 Berne C, Fagius J \& Niklasson F. Sympathetic response to oral carbohydrate administration. Journal of Clinical Investigation 198984 1403-1409.

18 Paramore DS, Fanelli CG, Shah SD \& Cryer PE. Forearm norepinephrine spillover during standing, hyperinsulinemia, and hypoglycemia. American Journal of Physiology 1998275 E872-E881.

19 Muntzel MS, Anderson EA, Johnson AK \& Mark AL. Mechanisms of insulin action on sympathetic nerve activity. Clinical and Experimental Hypertension 199517 39-50.

20 Sauter A, Goldstein M, Engel J \& Ueta K. Effect of insulin on central catecholamines. Brain Research 1983260 330-333.

21 Muntzel M, Beltz T, Mark AL \& Johnson AK. Anteroventral third ventricle lesions abolish lumbar sympathetic responses to insulin. Hypertension 199423 1059-1062.

22 Scherrer U \& Sartori C. Insulin as a vascular and sympathoexcitatory hormone. Implications for blood pressure regulation, insulin sensitivity and cardiovascular morbidity. Circulation $1997964104-4113$.

23 Laakso M, Edelman SV, Brechtel G \& Baron AD. Decreased effect of insulin to stimulate muscle blood flow in obese man. A novel mechanism for insulin resistance. Journal of Clinical Investigation 199085 1844-1852.
24 Laakso M, Edelman SV, Olefsky JM, Brechtel G, Wallace P \& Baron AD. Kinetics of in vivo muscle insulin-mediated glucose uptake in human obesity. Diabetes 199039 965-974.

25 Laakso M, Edelman SV, Brechtel G \& Baron AD. Impaired insulin-mediated skeletal muscle blood flow in patients with NIDDM. Diabetes 199241 1076-1083.

26 Laakso M, Edelman SV, Brechtel G \& Baron AD. Effects of epinephrine on insulin-mediated glucose uptake in whole body and leg muscle in humans: role of blood flow. American Journal of Physiology 1992263 E199-E204.

27 Capaldo B, Napoli R, Di Maino L \& Saccà L. Epinephrine directly antagonizes insulin-mediated activation of glucose uptake and inhibition of free fatty acid release in forearm tissues. Metabolism 199241 1146-1149.

28 Randin D, Vollenweider P, Tappy L, Jéquier E, Nicod P \& Scherrer U. Effects of adrenergic and cholinergic blockade on insulininduced stimulation of calf blood flow in humans. American Journal of Physiology 1994266 R809-R816.

29 Utriainen T, Malmström R, Mäkimattila S \& Yki-Järvinen H. Methodological aspects, dose-response characteristics and causes of interindividual variation in insulin stimulation of limb blood flow in normal subjects. Diabetologia 199538 555564.

30 Lundgren F, Edén E, Arfvidsson B \& Lundholm K. Insulin time dependent effects on the leg exchange of glucose and amino acids in man. European Journal of Clinical Investigation 199121 421-429.

31 Scherrer U, Randin D, Vollenweider P, Vollenweider L \& Nicod P. Nitric oxide release accounts for insulin's vascular effects in humans. Journal of Clinical Investigation 199494 2511-2515.

32 Neahring JM, Stepniakowski K, Greene AS \& Egan BM. Insulin does not reduce forearm alpha-vasoreactivity in obese hypertensive or lean normotensive men. Hypertension $199322584-$ 590.

33 Jamerson KA, Julius S, Gudbrandsson T, Andersson O \& Brant DO. Reflex sympathetic activation induces acute insulin resistance in the human forearm. Hypertension $199321618-$ 623.

34 Nuutila P, Raitakari M, Laine H, Kirvelä O, Takala K, Utriainen T, Mäkimattila S, Pitkänen O-P. Ruotsalainen U, Iida H, Knuuti J \& Yki-Järvinen $\mathrm{H}$. Role of blood flow in regulating insulinstimulated glucose uptake in humans. Studies using bradykinin, $\left[{ }^{15} \mathrm{O}\right]$ water, and $\left[{ }^{18} \mathrm{~F}\right]$ fluoro-deoxy-glucose and positron emission tomography. Journal of Clinical Investigation 1996971741 1747.

35 Raitakari M, Nuutila P, Ruotsalainen U, Laine H, Teräs M, Iida H, Mäkimattila S, Utriainen T, Oikonen V, Sipilä H, Haaparanta M, Solin O, Wegelius U, Knuuti J \& Yki-Järvinen H. Evidence for a dissociation of insulin stimulation of blood flow and glucose uptake in human skeletal muscle. Studies using $\left[{ }^{15} \mathrm{O}\right] \mathrm{H}_{2} \mathrm{O}$, $\left.{ }^{18} \mathrm{~F}\right]$ fluoro-2-deoxy-D-glucose, and positron emission tomography. Diabetes $1996451471-1477$.

36 Utriainen T, Holmang A, Björntorp P, Makimattila S, Sovijarvi A, Lindholm $\mathrm{H}$ \& Yki-Järvinen $\mathrm{H}$. Physical fitness, muscle morphology, and insulin-stimulated limb blood flow in normal subjects. American Journal of Physiology 1996270 E905-E911.

37 Utriainen T, Makimattila S, Virkamaki A, Lindholm $\mathrm{H}$, Sovijarvi A \& Yki-Järvinen H. Physical fitness and endothelial function (nitric oxide synthesis) are independent determinants of insulin-stimulated blood flow in normal subjects. Journal of Clinical Endocrinology and Metabolism 199681 4258-4263.

38 Sobrevia L, Nadal A, Yudilevich DL \& Mann GE. Activation of Larginine transport (system $\mathrm{y}+$ ) and nitric oxide synthase by elevated glucose and insulin in human endothelial cells. Journal of Physiology $1996490775-781$.

39 Zeng G \& Quon MJ. Insulin-stimulated production of nitric oxide is inhibited by wortmannin. Direct measurement in vascular endothelial cells. Journal of Clinical Investigation 199698 894898. 
40 Steinberg HO, Brechtel G, Johnson A, Fineberg N \& Baron AD Insulin-mediated skeletal muscle vasodilation is nitric oxide dependent. A novel action of insulin to increase nitric oxide release. Journal of Clinical Investigation 199494 1172-1179.

41 Verma S, Arikawa E, Yao L, Laher I \& McNeill JH. Insulininduced vasodilation is dependent on tetrahydrobiopterin synthesis. Metabolism 199847 1037-1039.

42 Lembo G, Iaccarino G, Vecchione C, Rendina V, Parella L \& Trimarco, B. Insulin modulation of $\beta$-adrenergic vasodilator pathway in human forearm. Circulation 199693 1403-1410.

43 Taddei S, Virdis A, Mattei P, Natali A, Ferrannini E \& Salvetti A. Effect of insulin on acetylcholine-induced vasodilation in normotensive subjects and patients with essential hypertension. Circulation 199592 2911-2918.

44 Sartori C, Trueb L, Lepori M, Nicod P \& Scherrer U. L-NMMA impairs vasodilation and induces hypertension but not insulin resistance during insulin infusion in subjects with regional sympathectomy. Diabetes 199746 229A.

45 Mathias CJ, Da Costa DF, Fosbraey P, Christensen NJ \& Bannister, R. Hypotensive and sedative effects of insulin in autonomic failure. BMJ 1987295 161-163.

46 Sartori C, Trueb L \& Scherrer U. Insulin's direct vasodilator action in humans is masked by sympathetic vasoconstrictor tone. Diabetes $19964585 \mathrm{~A}$.

47 Sartori C, Trueb L, Nicod P \& Scherrer U. Effects of sympathectomy and nitric-oxide synthase inhibition on insulin's vascular actions in humans. Hypertension 199934 586-589.

48 Owlya R, Vollenweider L, Trueb L, Sartori C, Lepori M, Nicod P \& Scherrer U. Cardiovascular and sympathetic effects of nitric oxide inhibition at rest and during exercise in humans. Circulation 199796 3897-3903.

49 Lepori M, Sartori C, Trueb L, Owlya R, Nicod P \& Scherrer U. Hemodynamic and sympathetic effects of nitric-oxide synthase inhibition by systemic L-NMMA infusion in humans are dose dependent. Journal of Hypertension 199816 519-523.

50 Rabinowitz D \& Zierler KL. Forearm metabolism in obesity and its response to intra-arterial insulin. Characterization of insulin resistance and evidence for adaptive hyperinsulinism. Journal of Clinical Investigation 196241 2173-2181.

51 Tack CJ, Ong MK, Lutterman JA \& Smits P. Insulin-induced vasodilatation and endothelial function in obesity/insulin resistance. Effects of troglitazone. Diabetologia 199841 569-576.

52 Steinberg HO, Chaker H, Leaming R, Johnson A, Brechtel G \& Baron AD. Obesity/insulin resistance is associated with endothelial dysfunction. Journal of Clinical Investigation 1996 97 2601-2610.

53 Laine H, Yki-Järvinen H, Kirvela $O$, Tolvanen T, Raitakari M, Solin O, Haaparanta M, Knuuti J \& Nuutila P. Insulin resistance of glucose uptake in skeletal muscle cannot be ameliorated by enhancing endothelium-dependent blood flow in obesity. Journal of Clinical Investigation 1998101 1156-1162.

54 Hunter SJ, Harper R, Ennis CN, Sheridan B, Atkinson AB \& Bell PM. Skeletal muscle blood flow is not a determinant of insulin resistance in essential hypertension. Journal of Hypertension $19971573-77$

55 Anderson EA, Balon TW, Hoffman RP, Sinkey CA \& Mark AL. Insulin increases sympathetic nerve activity but not blood pressure in borderline hypertensive humans. Hypertension 1992 $19621-627$.

56 Laine H, Knuuti MJ, Ruotsalainen U, Utriainen T, Oikonen V, Raitakari M, Luotolahti M, Kirvela O, Vicini P, Cobelli C, Nuutila $\mathrm{P} \&$ Yki-Järvinen H. Preserved relative dispersion but blunted stimulation of mean flow, absolute dispersion, and blood volume by insulin in skeletal muscle of patients with essential hypertension. Circulation 199897 2146-2153.

57 Laine H, Knuuti MJ, Ruotsalainen U, Raitakari M, Iida H, Kapanen J, Kirvela O, Haaparanta M, Yki-Järvinen H \& Nuutila $\mathrm{P}$. Insulin resistance in essential hypertension is characterized by impaired insulin stimulation of blood flow in skeletal muscle. Journal of Hypertension 199816 211-219.
58 Heise T, Magnusson K, Heinemann L \& Sawicki PT. Insulin resistance and the effect of insulin on blood pressure in essential hypertension. Hypertension 199832 243-248.

59 Doria A, Fioretto P, Avogaro A, Carraro A, Morocutti A, Trevisan R, Frigato F, Crepaldi G, Viberti G \& Nosadini R. Insulin resistance is associated with high sodium-lithium countertransport in essential hypertension. American Journal of Physiology 1991261 E684-E691.

60 Baron AD, Brechtel-Hook G, Johnson A \& Hardin D. Skeletal muscle blood flow: a possible link between insulin resistance and blood pressure. Hypertension 199321 129-135.

61 Gudbjörnsdottir S, Elam M, Sellgren J \& Anderson EA. Insulin increases forearm vascular resistance in obese, insulin-resistant hypertensives. Journal of Hypertension 199614 91-97.

62 Natali A, Taddei S, Quinones Galvan A, Camastra S, Baldi S, Frascerra S, Virdis A, Sudano I, Salvetti A \& Ferrannini E. Insulin sensitivity, vascular reactivity, and clamp-induced vasodilatation in essential hypertension [see comments]. Circulation $199796849-855$.

63 Panza JA, Quyyumi AA, Brush JE \& Epstein SE. Abnormal endothelium-dependent vascular relaxation in patients with essential hypertension. New England Journal of Medicine 1990 $32322-27$.

64 Cockroft JR, Chowienczyk PJ, Benjamin N \& Ritter JM. Preserved endothelium-dependent vasodilation in patients with essential hypertension. New England Journal of Medicine $19943301036-$ 1040.

65 Panza JA, Garcia CE, Kilcoyne CM, Quyyumi AA \& Cannon RO 3rd. Impaired endothelium-dependent vasodilation in patients with essential hypertension. Evidence that nitric oxide abnormality is not localized to a single signal transduction pathway. Circulation 199591 1732-1738.

66 Linder L, Kiowski W, Bühler FR \& Lüscher TF. Indirect evidence for the release of endothelium-derived relaxing factor in human forearm circulation in vivo. Blunted response in essential hypertension. Circulation 199081 1762-1767.

67 Utriainen T, Nuutila P, Takala T, Vicini P, Ruotsalainen U, Ronnemaa T, Tolvanen T, Raitakari M, Haaparanta M, Kirvela $\mathrm{O}$, Cobelli $\mathrm{C} \&$ Yki-Järvinen $\mathrm{H}$. Intact insulin stimulation of skeletal muscle blood flow, its heterogeneity and redistribution, but not of glucose uptake in non-insulin-dependent diabetes mellitus. Journal of Clinical Investigation $1997100777-785$.

68 Kelley DE, Reilly JP, Veneman T \& Mandarino LJ. Effects of insulin on skeletal muscle glucose storage, oxidation, and glycolysis in humans. American Journal of Physiology 1990258 E923-E929.

69 Dela F, Mikines KJ, Sonne B \& Galbo H. Effect of training on interaction between insulin and exercise in human muscle. Journal of Applied Physiology 199478 2386-2393.

70 Dela F, Larsen JJ, Mikines KJ \& Galbo H. Normal effect of insulin to stimulate leg blood flow in NIDDM. Diabetes $199544221-$ 226.

71 Tack CJ, Smits P, Willemsen JJ, Lenders JW, Thien T \& Lutterman JA. Effects of insulin on vascular tone and sympathetic nervous system in NIDDM. Diabetes 199645 15-22.

72 Baron AD, Laakso M, Brechtel G \& Edelman SV. Reduced capacity and affinity of skeletal muscle for insulin-mediated glucose uptake in noninsulin-dependent diabetic subjects. Effects of insulin therapy. Journal of Clinical Investigation 1991 87 1186-1194.

73 Landsberg L. Diet, obesity and hypertension: a hypothesis involving insulin, the sympathetic nervous system and adaptive thermogenesis. Quarterly Journal of Medicine $19862361081-$ 1090 .

74 Avogaro A, Piarulli F, Valerio A, Miola M, Calveri M, Pavan P, Vicini P, Cobelli C, Tiengo A, Calo L \& Del Prato S. Forearm nitric oxide balance, vascular relaxation, and glucose metabolism in NIDDM patients. Diabetes 199746 1040-1046.

75 Watts GF, O'Brien SF, Silvester W \& Millar JA. Impaired endothelium-dependent and independent dilatation of forearm 
resistance arteries in men with diet-treated non-insulindependent diabetes: role of dyslipidaemia. Clinical Science 1996 $91567-573$

76 Makimattila S, Virkamaki A, Malmstrom R, Utriainen T \& Yki-Järvinen H. Insulin resistance in type I diabetes mellitus: a major role for reduced glucose extraction. Journal of Clinical Endocrinology and Metabolism 199681 707-712.

77 Raitakari M, Nuutila P, Knuuti J, Raitakari OT, Laine H, Ruotsalainen U, Kirvela O, Takala TO, Iida H \& Yki-Järvinen $\mathrm{H}$. Effects of insulin on blood flow and volume in skeletal muscle of patients with IDDM: studies using $\left[{ }^{15} \mathrm{O}_{\mathrm{H}_{2}} \mathrm{O},\left[{ }^{15} \mathrm{O}\right] \mathrm{CO}\right.$, and positron emission tomography. Diabetes 199746 2017-2021.

78 Makimattila S, Mantysaari M, Schlenzka A, Summanen P \& Yki-Järvinen H. Mechanisms of altered hemodynamic and metabolic responses to insulin in patients with insulindependent diabetes mellitus and autonomic dysfunction. Journal of Clinical Endocrinology and Metabolism 199883 468-475.

79 Makimattila S, Mantysaari M, Groop PH, Summanen P, Virkamaki A, Schlenzka A, Fagerudd J \& Yki-Järvinen $H$. Hyperreactivity to nitrovasodilators in forearm vasculature is related to autonomic dysfunction in insulin-dependent diabetes mellitus. Circulation 199795 618-625.

80 Baron AD, Laakso M, Brechtel G \& Edelman SV. Mechanism of insulin resistance in insulin-dependent diabetes mellitus: a major role for reduced skeletal muscle blood flow. Journal of Clinical Endocrinology and Metabolism 199173 637-643.

81 Makimattila S, Virkamaki A, Groop PH, Cockcroft J, Utriainen T, Fagerudd J \& Yki-Järvinen H. Chronic hyperglycemia impairs endothelial function and insulin sensitivity via different mechanisms in insulin-dependent diabetes mellitus. Circulation $1996941276-1282$.

82 Yki-Järvinen H \& Utriainen T. Insulin-induced vasodilatation: physiology or pharmacology? Diabetologia 199841 369-379.

83 Steinberg HO, Cressman E, Wu Y, Hook G, Cronin J, Johnson A \& Baron A. Insulin mediated nitric oxide production is impaired in insulin resistance. Diabetes $19974624 \mathrm{~A}$

84 Petrie JR, Ueda S, Webb DJ, Elliott HL \& Connell JMC. Endothelial nitric oxide production and insulin sensitivity. A physiological link with implications for pathogenesis of cardiovascular disease. Circulation 199693 1331-1333.

85 Scherrer U, Nussberger J, Torriani S, Waeber B, Darioli R, Hofstetter J-R \& Brunner HR. Effect of weight reduction in moderately overweight patients on recorded ambulatory blood pressure and free cytosolic platelet calcium. Circulation 199183 $552-558$

86 Andersson B, Elam M, Wallin BG, Björntop P \& Andersson OK. Effect of energy-restricted diet on sympathetic muscle nerve activity in obese women. Hypertension 1991 18 783-789.

87 Spraul M, Ravussin E, Fontvieille AM, Rising R, Larson DE \& Anderson EA. Reduced sympathetic nerve activity. A potential mechanism predisposing to body weight gain. Journal of Clinical Investigation 199392 1730-1735.

88 Grassi G, Seravalle G, Cattaneo BM, Bolla GB, Lanfranchi A Colombo M, Giannattasio C, Brunani A, Cavagnini F \& Mancia G. Sympathetic activation in obese normotensive subjects. Hypertension 199525 560-563.

89 Scherrer U, Owlya R \& Trueb L. Sympathetic-nerve activity before and after resection of an insulinoma. New England Journal of Medicine 1996335 1240-1242.

90 Tsutsu N, Nunoi K, Kodama T, Nomiyama R, Iwase M \& Fujishima M. Lack of association between blood pressure and insulin in patients with insulinoma. Journal of Hypertension 19908 479-482.

91 Harada S. Inhibition of nitric oxide formation in the nucleus tractus solitarius increases renal sympathetic nerve activity in rabbits. Circulation Research 199372 511-516.

92 Tagawa T, Imaizumi T, Harada S, Endo T, Shiramoto M, Hirooka Y \& Takeshita A. Nitric oxide influences neuronal activity in the nucleus tractus solitarius of rat brainstem slices. Circulation Research $19947570-76$.
93 Sakuma I, Togashi H, Yoshioka M, Saito H, Yanagida M, Tamura M, Kobayashi T, Yashuda H, Gross SS \& Levi R. $N^{\mathrm{G}}$-Methyl-Larginine, an inhibitor of L-arginine-derived nitric oxide synthesis, stimulates renal sympathetic nerve activity in vivo. Circulation Research 199270 607-611.

94 Sartori $C \&$ Scherrer U. Insulin as a vasoactive hormone. At the crossroad of metabolic and cardiovascular regulation. Journal of Hypertension 199917 1517-1525.

95 Miyamoto Y, Saito Y, Kajiyama N, Yoshimura M, Shimasaki Y, Nakayama M, Kamitani S. Harada M, Ishikawa M, Kuwahara K, Ogawa E, Hamanaka I, Takahashi N, Kaneshige T, Teraoka H, Akamizu T, Azuma N, Yoshimasa Y, Yoshimasa T, Itoh H, Masuda I, Yasue H \& Nakao K. Endothelial nitric oxide synthase gene is positively associated with essential hypertension. Hypertension 199832 3-8.

96 Wang XL, Sim AS, Badenhop RF, McCredie RM \& Wilcken DE. A smoking-dependent risk of coronary artery disease associated with a polymorphism of the endothelial nitric oxide synthase gene. Nature Medicine 19962 41-45.

97 Hingorani AD, Liang CF, Fatibene J, Lyon A, Monteith S, Parsons A. Haydock S, Hopper RV, Stephens NG, O'Shaughnessy KM \& Brown MJ. A common variant of the endothelial nitric oxide synthase (Glu298 $\rightarrow$ Asp) is a major risk factor for coronary artery disease in the UK. Circulation 1999100 1515-1520.

98 Steinberg HO \& Baron AD. Insulin-mediated vasodilation: why one's physiology could be the other's pharmacology. Diabetologia 199942 493-493 (Letter).

99 Yki-Järvinen H \& Utriainen T. Insulin-mediated vasodilation: the author's reply. Diabetologia 199942 494-495.

100 Clark MG, Colquhoun EQ, Rattigan S, Dora KA, Eldershaw TP, Hall JL \& Ye J. Vascular and endocrine control of muscle metabolism. American Journal of Physiology 1995268 E797E812.

101 Baron AD, Steinberg HO, Brechtel G \& Johnson A. Skeletal muscle blood flow independently modulates insulin-mediated glucose uptake. American Journal of Physiology 1994266 E248E253.

102 Baron AD, Steinberg HO, Chaker H, Leaming R, Johnson A \& Brechtel G. Insulin-mediated skeletal muscle vasodilation contributes to both insulin sensitivity and responsiveness in lean humans. Journal of Clinical Investigation 199596 786-792.

103 Butler R, Morris AD \& Struthers AD. Systemic nitric oxide synthase inhibition increases insulin sensitivity in man. Clinical Science 199894 175-180.

104 Young ME, Radda GK \& Leighton B. Nitric oxide stimulates glucose transport and metabolism in rat skeletal muscle in vitro. Biochemical Journal 1997322 223-228.

105 Balon TW \& Nadler JL. Evidence that nitric oxide increases glucose transport in skeletal muscle. Journal of Applied Physiology 199782 359-363.

106 Balon TW. Role of nitric oxide in contraction induced glucose transport. Advances in Experimental Medicine and Biology 1998 $44187-95$.

107 Roberts CK. Barnard RJ. Scheck SH \& Balon TW. Exercisestimulated glucose transport in skeletal muscle is nitric oxide dependent. American Journl of Physiology 1997273 E220E225.

108 Shepherd PR \& Kahn BB. Glucose transporters and insulin action - implications for insulin resistance and diabetes mellitus. New England Journal of Medicine 1999341 248-257.

109 Wascher TC, Graier WF, Dittrich P, Hussain MA, Bahadori B, Wallner S \& Toplak H. Effects of low-dose L-arginine on insulinmediated vasodilatation and insulin sensitivity. European Journal of Clinical Investigation 199727 690-695.

110 Shankar R, Zhu JS, Ladd B, Henry D, Shen HO \& Baron AD. Central nervous system nitric oxide synthase activity regulates insulin secretion and insulin action. Journal of Clinical Investigation 1998102 1403-1412.

111 Roy D, Perreault M \& Marette A. Insulin stimulation of glucose uptake in skeletal muscles and adipose tissues in vivo is NO 
dependent. American Journal of Physiology 1998274 E692E699.

112 Trueb L, Sartori C \& Scherrer U. Insulin resistance evoked by orthostasis-induced sympathetic activation is $\alpha$-adrenergically mediated. Diabetes 199645 97A.

113 Lembo G, Capaldo B, Rendina V, Iaccarino G, Napoli R, Guida R, Trimarco B \& Saccà L. Acute noradrenergic activation induces insulin resistance in human skeletal muscle. American Journal of Physiology 1994266 E242-E247.

114 Tappy L, Girardet K, Schwaller N, Vollenweider L, Jéquier E, Nicod P \& Scherrer U. Metabolic effects of an increase of sympathetic activity in healthy humans. International Journal of Obesity $199519419-422$.

115 Tomiyama H, Kushiro T, Abeta H, Ishii T, Takahashi A, Furukawa L, Asagami T, Hino T, Saito F, Otsuka Y, Kurumatan $\mathrm{H}$, Kobayashi K \& Kajiwara N. Kinins contribute to the improvement of insulin sensitivity during treatment with angiotensin converting enzyme inhibitor. Hypertension 1994 23 450-455.

116 Pollare T, Lithell H, Selinus I \& Berne C. Application of prazosin is associated with an increase of insulin sensitivity in obese patients with hypertension. Diabetologia 198831 415-420.

117 Leimbach WN, Wallin BG, Victor RG, Aylward PE, Sundlöf G \& Mark AL. Direct evidence from intraneural recordings for increased central sympathetic outflow in patients with heart failure. Circulation 198673 913-919.

118 Shen D-C, Shieh S-M, Fuh MMT, Wu D-A, Chen Y-DI \& Reaven GM. Resistance to insulin-stimulated glucose uptake in patients with hypertension. Journal of Clinical Endocrinology and Metabolism 198866 580-583.

119 Marigliano A, Tedde R, Sechi LA, Pala A, Pisanu G \& Pacifico A. Insulinemia and blood pressure. Relationships in patients with primary and secondary hypertension, and with and without glucose metabolism impairment. American Journal of Hypertension $19903521-526$.
120 Shamiss A, Carroll J \& Rosenthal T. Insulin resistance in secondary hypertension. American Journal of Hypertension 1992 $526-28$

121 Allemann Y, Horber FF, Colombo M, Ferrari P, Shaw S, Jaeger P \& Weidmann P. Insulin sensitivity and body fat distribution in normotensive offspring of hypertensive parents. Lancet 1993 $341327-331$

122 Bevan RD. Trophic effects of peripheral adrenergic nerves on vascular structure. Hypertension 19846 (Suppl 3) III19-III26

123 Sloan JA, Hooper M \& Izzo JL Jr. Effects of circulating norepinephrine on platelets, leukocyte and RBC counts by alpha $_{1}$-adrenergic stimulation. American Journal of Cardiology 198963 1140-1142.

124 Ruschitzka FT, Noll G \& Luscher TF. The endothelium in coronary artery disease. Cardiology 199788 (Suppl 3) 3-19.

125 Wang BY, Ho HK, Lin PS, Schwarzacher SP, Pollman MJ, Gibbons GH, Tsao PS \& Cooke JP. Regression of atherosclerosis: role of nitric oxide and apoptosis. Circulation $1999991236-$ 1241.

126 Toutouzas PC, Tousoulis D \& Davies GJ. Nitric oxide synthesis in atherosclerosis. European Heart Journal 199819 1504-1511.

127 Jiang Z, Lin YW, Clermont A, Igarashi M \& King G. Direct demonstration of selective insulin resistance on PI3-kinase pathway in vascular tissues of obese Zucker (fa/fa) rats. Diabetes 199746 54A.

128 Noon JP, Walker BR, Webb DJ, Shore AC, Holton DW, Edwards HV \& Watt GC. Impaired microvascular dilatation and capillary rarefaction in young adults with a predisposition to high blood pressure. Journal of Clinical Investigation 199799 1873-1879.

129 Hudlicka O, Brown M \& Egginton S. Angiogenesis in skeletal and cardiac muscle. Physiological Reviews 199272 369-417.

Received 2 August 1999

Accepted 29 December 1999 